\title{
Government's influence on the implementation of BIM
}

\author{
Lucy Atkinson ${ }^{1}$, Joseph Amoako-Attah ${ }^{2}$ and Ali B-Jahromi ${ }^{3}$ \\ ${ }^{1}$ Mansell Construction Services Ltd, London Special Projects, Roman House, \\ City Road, London EC1V1JX \\ ${ }^{2,3}$ University of West London, School of Computing and Technology, Dept. of \\ the Built Environment, St Mary’s Road, Ealing, London W5 5RF
}

\begin{abstract}
The government's construction strategy requires construction projects for central government to implement level 2 building information modelling as a minimum by 2016. Since it was published a number of specifications, plans and processes have been released. Government has been involved in their production through being part of steering groups and explaining what they, as construction clients and occupiers of a huge number of built assets, need from the industry. Department projects have also been used to trial new methods and provide feedback from both the client's and the project team's point of view. The government's involvement has resulted in a coordinated response from an industry that is traditionally very fragmented and introduced a real impetus for changing the way the construction industry works and embracing digital technology.
\end{abstract}

\section{INTRODUCTION}

Why has government become so involved in BIM?. Property, construction and facilities management form significant part of central government and public services' budgets and account for 15\% of UK GDP with construction at about $6.7 \%$ of GDP (Saxon 2013) and 40\% being public sector expenditure (Cabinet Office 2011). The risks of overspend and high delays in the construction industry are a disincentive for banks to offer good rates for investment. The cost of operating and maintaining government and public sector funded built assets throughout their lifecycle far outweighs the initial capital cost. The traditional built environment processes rely heavily on repeated manual input and are fragmented between design, construction and handover to the client (Forbes 2012). Waste elimination and value added delivery projects entails superior methods in design and management of flow of data. More certainty of cost and outcome is needed for clients to confidently undertake projects and raise the capital investment required.

During this period of prolonged recession the focus on reducing cost and waste, whilst achieving carbon reduction targets, are high on the Government's agenda. The Climate Change Act 2008 committed the UK to reduce greenhouse gas emissions by $80 \%$ (from the 1990 baseline) by 2050. Low carbon methods of providing energy and reducing energy consumption are an immediate priority for the industry. The Construction Strategy 2011 is seeking a cost reduction of $20 \%$ by 2015 and requires construction projects for central government to implement 
level 2 BIM as a minimum by 2016 regardless of the value of the project. The strategy identifies the lagging of construction behind other industries in the adoption of digital technology which prevents full collaborative working environment. A core principle of Level 2 BIM is the shared use of individually authored models, in a common data environment (British Standards Institute and Richards 2013) and for it to work the data needs to be managed consistently.

Moreover, the Government Soft Landings Policy (GSL) seeks to 'align the interests of those who design and construct an asset with those who subsequently use it' (Government Property Unit 2012). Whilst BIM is defined as "delivering the right information to the right people at the right time" (Throssell 2012), the concept of GSL provides feedback on occupancy information to facilitate the improvement in designs and provide better buildings. BIM and GSL have been earmarked as essential for the energy outputs to be clearly defined and monitored throughout each stage of the design, construction and occupation of the building. The government mandating GSL implementation by 2016 in line with level 2 BIM will significantly increase the uptake.

But how are government and institution bodies assisting the industry to facilitate the integrated and efficient project delivery change in a coordinated and consistent manner? Table 1 contains a summary of strategies, policies, standards and processes relating to the implementation of BIM published by government bodies and the industry's institutions. These aim to provide detailed consistent guidance to companies of all sizes and disciplines. The publically available specification - PAS 1192-2 - is the central and most informative document as it explains how the other documents and processes fit together. It also provides specific guidelines on the management of information in a BIM environment. The associated standard BS 1192, provides a disciplined process for collaboration and a specified naming policy (BSI 2007). It defines areas within a common data environment and provides a naming and classification structure for models, drawings and documents. Adhering to the BS 1192 is an indication that information can be managed accurately in a collaborative common data environment.

Table 1. Summary of information

\begin{tabular}{|c|c|c|}
\hline Release Date & Title & Author / Publisher \\
\hline 2007 & $\begin{array}{l}\text { BS 1192:2007 Collaborative production of } \\
\text { architectural, engineering and construction } \\
\text { information - Code of practice }\end{array}$ & British Standards Institute \\
\hline $\begin{array}{l}\text { February } \\
2011\end{array}$ & CPIx BIM Assessment Form & $\begin{array}{l}\text { Construction } \\
\text { Information }\end{array}$ \\
\hline $\begin{array}{l}\text { February } \\
2011\end{array}$ & CPIx IT Assessment Form & $\begin{array}{l}\text { Construction } \\
\text { Information }\end{array}$ \\
\hline March 2011 & BIM Working Party Strategy Paper & $\begin{array}{l}\text { Cabinet Office department of } \\
\text { Business Innovation and Skills } \\
\text { (BIS) }\end{array}$ \\
\hline $\begin{array}{lr}\text { May } & 2011 \\
\text { and } & \text { update } \\
2012 & \\
\end{array}$ & $\begin{array}{l}\text { Government Construction Strategy } 2011 \\
\text { One Year on Report and Action Plan } \\
\text { Update } 2012\end{array}$ & Cabinet Office \\
\hline 2011 & BIM Task Group & $\begin{array}{l}\text { www.bimtaskgroup.org } \\
\text { Brings together industry, } \\
\text { government, public sector, } \\
\text { institutes and academia }\end{array}$ \\
\hline
\end{tabular}




\begin{tabular}{|c|c|c|}
\hline $\begin{array}{l}\text { September } \\
2012\end{array}$ & Government Soft Landings Policy & $\begin{array}{l}\text { Cabinet Office Government } \\
\text { Property Unit - } \\
\text { implementation being managed } \\
\text { through BIM Task Group }\end{array}$ \\
\hline $\begin{array}{l}\text { February } \\
2012\end{array}$ & COBie-12-uk & BuildingSMARTalliance \\
\hline $\begin{array}{l}\text { January } 2013 \\
- \text { trial under } \\
\text { development } \\
\end{array}$ & Uniclass2 Beta Classification & $\begin{array}{l}\text { Construction Project } \\
\text { Information Committee and } \\
\text { institution members }\end{array}$ \\
\hline $\begin{array}{l}\text { February } \\
2013\end{array}$ & $\begin{array}{l}\text { PAS 1192-2 Specification for information } \\
\text { management for the capital/delivery phase } \\
\text { of construction projects using building } \\
\text { information modelling }\end{array}$ & $\begin{array}{l}\text { Sponsored by Construction } \\
\text { Industry Council, published by } \\
\text { British Standards Institute }\end{array}$ \\
\hline $\begin{array}{l}\text { February } \\
2013\end{array}$ & $\begin{array}{llll}\begin{array}{l}\text { Building } \\
\text { Protocol }\end{array} & \text { Information } & \text { Model } & \text { (BIM) } \\
\end{array}$ & Construction Industry Council \\
\hline $\begin{array}{l}\text { February } \\
2013\end{array}$ & $\begin{array}{l}\text { Outline Scope of Services for the role of } \\
\text { Information Management }\end{array}$ & Construction Industry Council \\
\hline $\begin{array}{l}\text { February } \\
2013\end{array}$ & Lab Space & BIM Task Group \\
\hline March 2013 & Digital Plan of Work (Work in Progress) & BIM Task Group/Labs \\
\hline March 2013 & Data Hierarchy (Work in Progress) & BIM Task Group/Labs \\
\hline Early 2013 & COBie Extracting and Testing Tools & $\begin{array}{l}\text { BIM Task Group/Labs Trials: } \\
\text { testing COBie extraction and } \\
\text { testing tools }\end{array}$ \\
\hline March 2013 & $\begin{array}{l}\text { CPIx Post Contract-Award BIM Execution } \\
\text { Plan }\end{array}$ & $\begin{array}{l}\text { Construction } \quad \text { Project } \\
\text { Information }\end{array}$ \\
\hline March 2013 & $\begin{array}{l}\text { PAS } 91 \text { Construction Prequalification } \\
\text { Questionnaires }\end{array}$ & British Standards Institute \\
\hline March 2013 & $\begin{array}{l}\text { ISO 16739:2013 Industry Foundation } \\
\text { Classes (IFC) for data sharing in the } \\
\text { construction and facility management } \\
\text { industries }\end{array}$ & $\begin{array}{l}\text { International Organisation for } \\
\text { Standardisation (ISO) }\end{array}$ \\
\hline Planned & $\begin{array}{l}\text { PAS 1192-3 Guidance on asset } \\
\text { information model }\end{array}$ & $\begin{array}{l}\text { Sponsored by Construction } \\
\text { Industry Council, published by } \\
\text { British Standards Institute }\end{array}$ \\
\hline $\begin{array}{lr}\text { Planned for } \\
\text { release } \\
2013\end{array}$ & CIC Scope of Services & Construction Industry Council \\
\hline $\begin{array}{lr}\text { Planned } & \text { for } \\
\text { release } & \text { in } \\
2013 & \\
\end{array}$ & RIBA Plan of Works updated & RIBA \\
\hline $\begin{array}{l}\text { Planned } \\
\text { update }\end{array}$ & BISRIA Design Framework updated & BISRIA \\
\hline
\end{tabular}




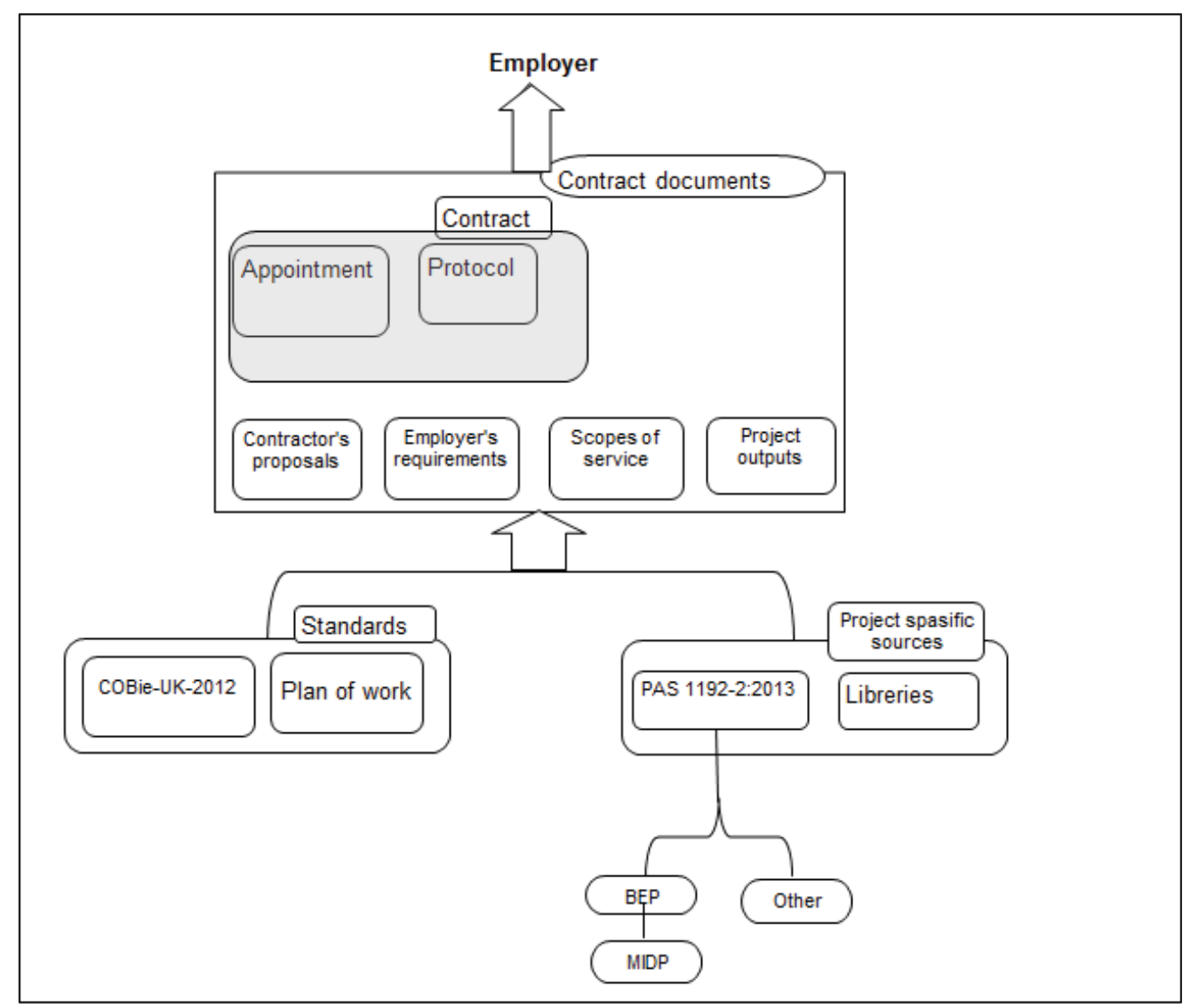

Figure 1. Relationships between the contract and the associated documents.

Procurement, post contract-award, mobilization and production information delivery. Figure 2 detailed the relationship between documents used for information management and identifies the various tools which facilitate information management collaboration by all organisation in the supply chain. Amongst these tools are the Employer's Information Requirements (EIR) which must be included at tender so that suppliers can produce their initial BIM Execution Plan (BEP). The supplier BIM assessment forms and supplier information technology assessment forms are to be completed by all appropriate organisations within the supply chain so that the supply chain capability can be assessed and summarised. The employer uses the Project Implementation Plan (PIP) to assess the suppliers' bids. The Construction Project Information website, CPIx On line tools provides templates for the BEP and assessment forms. Following contract award the BIM execution plan is updated and task team managers produce task information delivery plans (TIDP). The TIDP is part of the BEP and used to produce the master information delivery plan (MIDP). Contract documentation such as RIBA Plan of Works, CIC Scope of Services or BISRIA Design Framework are currently being updated to align with PAS 1192-2 and the documents referenced within it. The information management processes need to be in place before the design work begins. The software, IT system requirements and common data environment are procured at this point if they aren't already established. Training needs in the immediate project team and throughout the supply chain also need to be addressed. During production the project information 
model (PIM) is developed in the common data environment in accordance with BS 1192:2007.

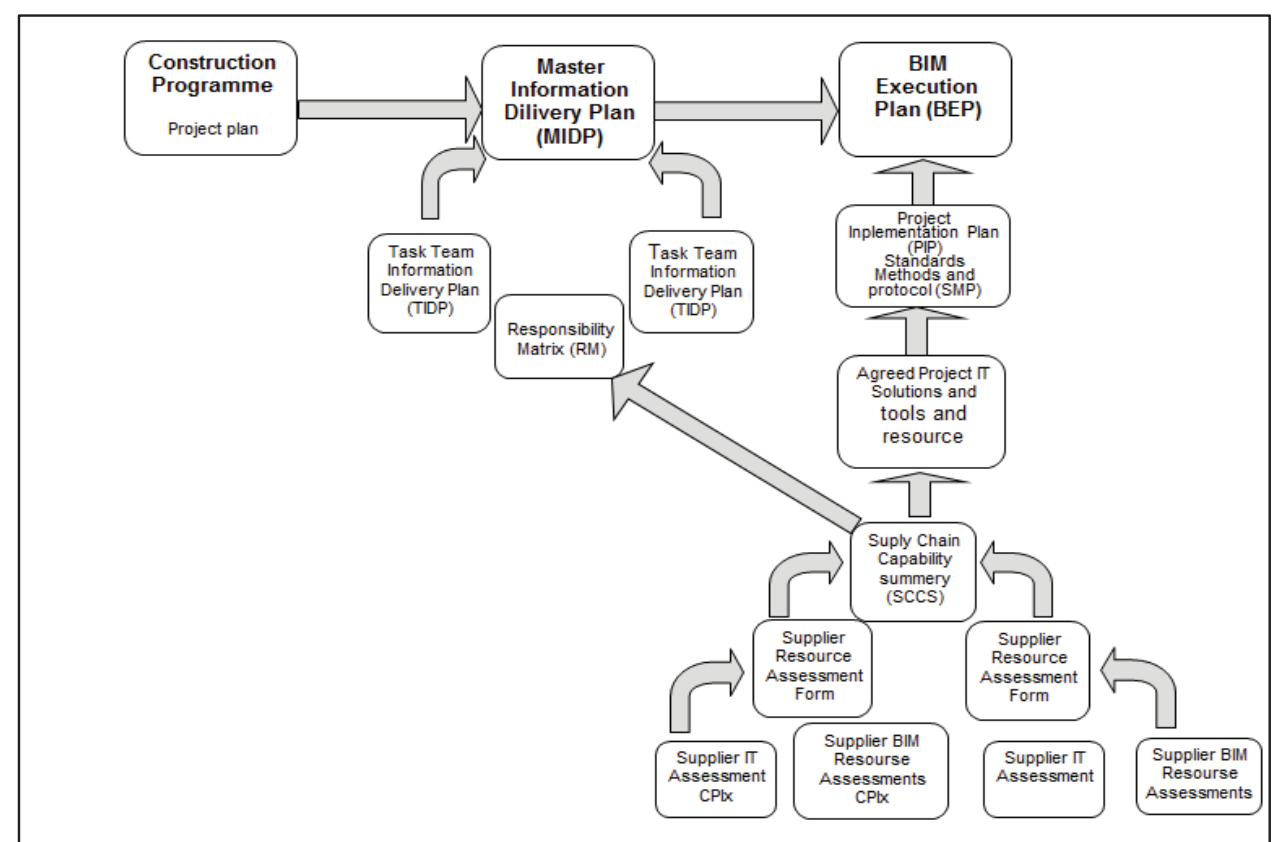

Figure 2. Relationship between documents used for information management

The 'Labs' area of the BIM Task Group website contains documents and processes that are currently under development. The draft digital plan of work has been produced to describe and provide clarity on how data is to be defined, tested and used by the supply chain and the public client (BIM Task Group 2013). Figure 3 illustrates how some of the new terminology and process fit together. The new 0 to 7 plan of work stages is to be adopted by the CIC Scope of Services, RIBA Plan of Work and BSRIA Design Framework. The intention is that other institutions that produce plans of work for the project lifecycle also adopt these work stages so that there is consistency across the industry. The stages have been named so that they apply to all types of construction: buildings, infrastructure and civil projects. The Levels of Detail tables in the PAS and digital plan of work are taken from the CIC document suite; each of the institutions that produce their own plans of work will set the levels of detail within them. The plain English questions in the Lab space on the BIM Task Group website have been provided by the Ministry of Justice. Their purpose is for the client to explain what they need to know so that they can make decisions to proceed at each stage of the project. The attribute demand matrix is used identify the information required for each object so that a set of information to the correct level of detail can be provided at each stage.

Software tools for everyone. The government does not seek to favour one software vendor over another and is leaving industry and market competition to determine how the products develop. However, the government wants interoperable standards for software so that the market can move towards level 3 BIM in a truly collaborative way. BuildingSMART is an alliance of organisations working towards improved methods of sharing information 
(BuildingSMARTAlliance 2012). In order to encourage interoperability of different software packages they have produced a series of standards called Industry Foundation Classes (IFC) (Crotty 2012) that enables data to be sharable regardless of the software vendor.

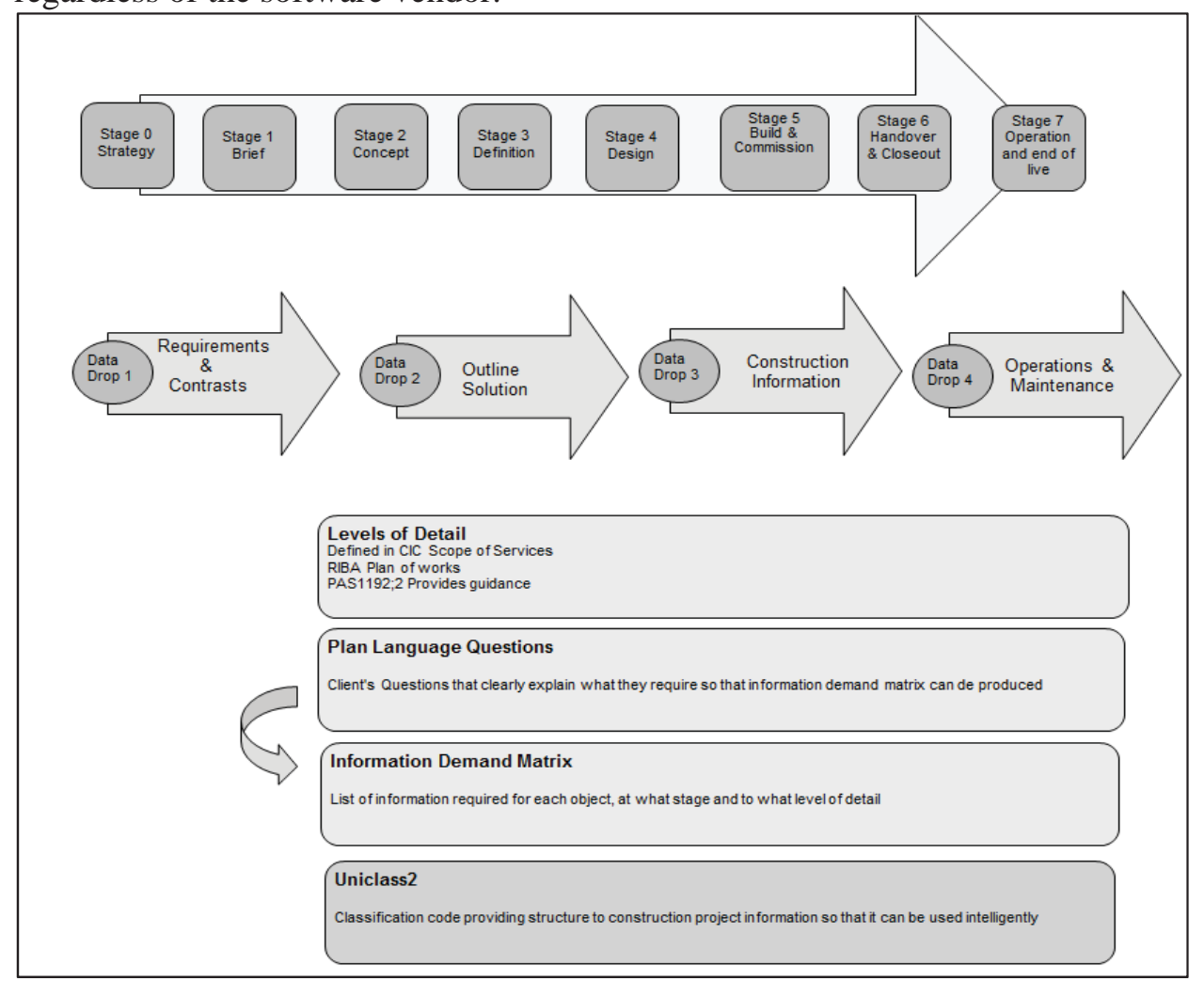

Figure 3. Relationship between stages of the project and data production

Development of IFC is paramount to true collaboration and it is important that the government continues to support open, non-proprietary standards (Malleson 2013). Moreover, to establish standards that require open interoperable software governments in interested nations need to work together to insist that software meets standards of interoperability and develop strict accreditation schemes to deter vendors from taking the proprietary approach. Incorporating cloud computing could also enable software licences to be bought for a project and shared with members of the project in different companies by license to their remote device. This could benefit SMEs by enabling them to use a software tool required by the project without the scale of investment being prohibitive. It also improves access to information on site and supports the use of geographic information systems.

\section{CONCLUSION}

Building Information Modelling - a front-end holistic approach to the creation of a truly collaborative supply chain throughout a project lifecycle is set to revolutionise the Architectural, Engineering and Construction industry. The requirement of the civil engineering community to achieve real efficiencies in the AEC industry highlights the need for collaboration, integration and finding a common language for all. Building information modelling is strongly backed by 
the government for all types of future assets including infrastructure and civil engineering. The government's influence on the implementation of BIM will facilitate the delivery mechanism for all United Kingdom publicly funded construction projects by 2016. The government has influenced the development and publishing of several key documents which detail the strategies, polices, standards and processes relating to the implementation of BIM. The recent specifications, processes, classifications and definitions all need to be used, commented on and developed so that they provide the industry with consistent methods of delivering projects efficiently. The Ministry of Justice is an early adopter of BIM and has set a target to mandate that all projects adopt level 2 BIM in 2013. They have undertaken a number of trials and the lessons learnt during the tender process. However, the industry needs to see government and other clients using the information provided and finding it of real benefit and the Central government also needs to improve its procurement methods to avoid contractors incurring unnecessary costs during tendering. Government seeks to make Britain a 'Digital Built Britain' where data is used to achieve major efficiencies and enable better plans for future services and projects, industry now need to make it a reality.

BIM is only one of thirteen components in the construction strategy 2011 which aim to improve the efficiency and quality of the construction industry by making government a more influential construction client and user of built assets, however; it brings together the other initiatives and enables these improvements to be made. The overall response from industry is that government is on the right track with its strategy and that by defining levels 1,2 and 3 they have provided steps to encourage all tiers to get started. Adoption of the government's strategy has made the UK a world leader in BIM and there is an opportunity to promote British standards internationally to boost construction exports and develop these skills within the UK.

\section{REFERENCES}

Beale and Company (February 2013) BIM Protocol. 1st ed. BIM Task Group: Construction Industry Council.

Bennetts, R., Bunn, R., Way, M. \& Leaman, A. (2009) BSRIA Soft Landings Framework.BSRIA Web Site [Online]. Available at: https://www.bsria.co.uk/services/design/soft-landings/guidance/ [Accessed: 04/04/2013].

BIM Industry Working Group (2011) Strategy Paper for the Government Construction Client Group from the BIM Industry Working Group March 2011. UK: Government Department of Business Innovation and Skills.

BIM Task Group (2013) Data Hierarchy [Online]. Available at: http://www.bimtaskgroup.org/task-group-labs-portal/ [Accessed: March 2013].

BIM Task Group (2013) BIM The Digital Plan of Work \& Assemblies. 7th ed. BIM Task Group.

Blackwell, B. (2012) HM Government Industrial Strategy: government and industry in partnership. UK: Government Department for Business Innovation and Skills.

British Standards Institute (March 2013) PAS 91 Construction prequalification questionnaires. First ed. UK: British Standards Institute.

British Standards Institute (2007) BS1192 Collaborative production of architectural, engineering and construction information - Code of practice. UK

British Standards Institute, Richards, M. (2013) PAS1192-2 Specification for informationNmanagement for the capital/delivery phase of construction 
projects using building information modelling. 1st ed. BIM Task Group: British Standards Institute.

BuildingSMARTAlliance (2012). What is buildingSMART? [Online]. Available at: http://www.buildingsmart.org.uk/Plone/buildingSMART/ what-is-the-iai/ [Accessed: 04/04/2013].

Cabinet Office (2011) Government Construction Strategy. http://www.cabinetoffice.gov.uk/resource-library/government-construction strategy: Cabinet Office.

Cabinet Office (2012) Government Construction Strategy - One Year On Report and Action Plan Update. http://www.cabinetoffice.gov.uk/ resourcelibrary/government-construction-strategy: Cabinet Office.

Chapman, I. (2012) The IFC/COBie Report 2012<br />Foreword. (1st). CPIC (2011) IT Assessment Form. V.01 ed. [Online]. Available at:http://www.cpic.org.uk/en/cpix-on-line-tools/cpix-bim-strategytemplates/index.cfm; [Accessed: 04/04/2013].

Crotty, R. (2012) The impact of building information modelling: transforming construction. London: Spon

Department of Energy \& Climate Change (2011) Carbon Plan Executive Summary. www.gov.uk: Cabinet Office

East, E.W. (2012) Construction Operations Building information exchange (COBie).[Online]. Available at: http://www.buildingsmartalliance.org/ index.php/projects/activeprojects/25.

Evans, R. (2013) Project delays smack of government hypocrisy. 1st ed. UK: ConstructionNNews.

Fitzpatrick, T. (2012) MoJ extends BIM trials and saves $£ 800 \mathrm{k}$ on first project. Construction News.

Forbes, G. (2012) Investing in BIM: A Guide for Architects. Building Design White Papers, (01), p.89.

Government Property Unit (2012) The Government Soft Landings Policy September 2012. UK: Cabinet Office.

Hansford, M. (2013) Why BIM's future is written in the cloud. 03rd ed. NCE Magazine:

New Civil Engineer. HM Government Innovation \& Growth Team (2010) Low Carbon Construction.www.gov.uk: Government

International Organisation for Standardisation (2013) ISO 16739:2013 Industry Foundation Classes (IFC) for data sharing in the construction and facility management industries. ISO.

Malleson, A. (2013) National BIM Report 2013. NBS, [Online]. Available at: http://www.thenbs.com/topics/BIM/reports/ [Accessed: 09/04/2013].

Malleson, A., Mordue, S. \& Hamil, S. (2012) The IFC/COBie Report 2012 Foreword.

Ministry of Justice \& BIM Task Group (February 2013) BIM Lessons Learnt. Ministry of Justice.

Philp, D. (2013) National BIM Report 2013. NBS, [Online]. Available at: http://www.thenbs.com/topics/BIM/reports/ [Accessed: 09/04/2013].

Saxon, R.G. (2013) Growth through BIM. CIC UK: Construction Industry Council. Throssell, D. (2012) Investing in BIM: A Guide for Architects. Building Design WhitePapers, (01), p.90. bdonline through work [Online]. Available at: http://www.bdonline.co.uk/home/the-bim-white-paper/5034325.article;

Waterhouse, R., Morrell, P., Klaschka, R., Kell, A., Clark, N., Collard, S., King, A. \& Hamil, S. (2011) 'BIM Roundtable Discussion'. NBS, NBS. 